\title{
145. Klinische Erfahrungen mit dem Ersatz von Herzwand und Septum durch Gore-Tex ${ }^{\circledR}$
}

\author{
H. Oelert, J. Frömke, G. Frank, H. G. Borst \\ Klinik für Thorax-, Herz- und Gefäßchirurgie, Medizinische Hochschule Hannover, \\ Konstanty-Gutschow-Straße 8, D-3000 Hannover 61
}

\section{Clinical Experience with Gore-Tex as a Substitute for Heart Wall and Septal Reconstructions}

Summary. During intracardiac correction of congenital heart lesions 436 Gore-Tex patches obtained from vascular protheses were implanted in 303 operations. Patch implantation occurred 356 times for atrial septal and/or wall graft in transposition of the great arteries and 80 times for reconstruction of the right ventricular outflow tract in Fallot's tetralogy. - Patch material saved during reoperation after 5 years was covered by a thin layer of fibrous tissue on both surfaces. Good collagen production was noted throughout the entire graft wall. The advantages of the Gore-Tex vascular graft (good incorporation, primary impermeability, high pressure resistance) can equally be transmitted to the Gore-Tex patch.

Key words: Gore-Tex - Prosthetic patch - Congenital heart disease - Intracardiac correction.

Zusammenfassung. Im Rahmen der Korrektur angeborener Herzfehler wurden in 303 Operationen 436mal aus Gore-Tex-Prothesen gewonnene Flicken implantiert. 356mal wurde der Flicken als Vorhofseptum- bzw. -wandersatz bei Transpositionen der großen Arterien eingesetzt, 80mal als Erweiterungsplastik des rechten Ventrikels bei der Fallotschen Tetralogie. Anläßlich von Reoperationen zurückgewonnene Kunststoff-Flicken zeigten nach 5 Jahren an beiden Grenzflächen ein zartes fibröses Polster sowie histologisch eine vollständige Durchdringung mit kernhaltigen Fibroblasten und kollagenen Fasern. - Die Vorzüge der Gore-TexGefäßprothese (gute Einheilung, primäre Bluttrockenheit, hohe Widerstandsfähigkeit gegenüber Druckbelastung) lassen sich zwanglos auf den Patch übertragen.

Schliisselwörter: Gore-Tex - Prothesenflicken - Angeborene Herzfehler - Intrakardiale Korrektur.

\section{Vergleich verschiedener OP-Verfahren zur Korrektur von Aortenisthmusstenosen im Säuglingsalter}

\author{
H. Storch, W. Saggau, A. Tanzeem, W. Schmitz, H. Ulmer und D. Wolf \\ Chirurgische Universitätsklinik Heidelberg, Abteilung für Spezielle Thoraxchirurgie, \\ Im Neuenheimer Feld 110, D-6900 Heidelberg
}

\section{Comparison of Operative Techniques for Correction of Coarctation of the Aortic Isthmus}

Summary. Between 1952 and August 1982, a total of 562 operations was carried out for the correction of coarctation of the aortic isthmus. During the last 4 years, the Waldhausen angioplasty technique has been followed in the initial neonatal period ( $1-30$ days) and a Gortex patch has been used in infants up to the age of 1 year. In comparison to end-to-end anastomosis $(40 \%$, which was used up to 1978 , there has been a drop in mortality (Waldhausen method $0 \%$; Gortex patch $4 \%$ ). This improvement is due to early diagnosis in the neonatal period, operation before the onset of myocardial insufficiency and the change in operative technique, as the main causes of failure of end-to-end anastomosis were restenosis and thrombosis of the anastomosis. Key words: Coarcation of aorta - Waldhausen angioplasty.

Zusammenfassung. Von 1952-8/82 wurden 564 Patienten wegen einer Aortenisthmusstenose operiert. In der Neugeborenenperiode $(1-30 \mathrm{Tg})$ führen wir seit 4 Jahren die Angioplastik nach Waldhausen durch, bis zu einem Alter von 12 Monaten, die Erweiterungsplastik mit Gortex. Die Letalität bei dem nach WaldhausenTechnik operierten Kindern lag bei $0 \%$, bei der Patchplastik bei $4 \%$. Bei der von 1978 mit der End-zu-End Technik operierten Kindern betrug die Letalität $40 \%$. Die verbesserten OP-Ergebnisse sind sowohl auf die frühzeitige Indikationsstellung zur OP insbesondere im Neugeborenenalter vor Auftreten einer Herzinsuffizienz zurückzuführen, als auch auf das geänderte OP-Verfahren. Denn Restenosierungen und Thrombosierungen waren die häufigste Todesursache in der Neugeborenenperiode.

Schlüsselwörter: Angioplastik nach Waldhausen - Erweiterungsplastik mit Gortex - Aortenisthmusstenose. 